\title{
Self-hypnosis Model Reduces Anxiety and Pain in Post-general Anesthesia Patients
}

\author{
Tri Prabowo* \\ Department of Nursing, Poltekkes Kemenkes Yogyakarta, Yogyakarta, Indonesia
}

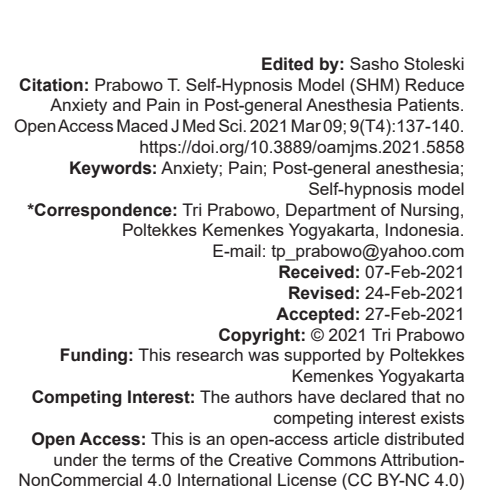

\begin{abstract}
BACKGROUND: General psychological responses are related to fear of anesthesia, pain, uncertain diagnosis, malignancy, incompetence, failure, surgical room environment, and horrifying stories from others. Excessive physiological responses tend to complicate and affect anesthetic actions.

AIM: This study aims to determine the effect of self-hypnosis model (SHM) on the reduction of anxiety and pain in patients after general anesthesia.

METHODS: There was a quasi-experimental study with pretest-posttest design with control design. Respondents were recruited using simple random sampling technique. Forty respondents were divided into two groups: Intervention (20) and control (20). State Trait Anxiety Inventory (STAI) and the Numerical Pain Rating Scale were used to measure pain. Data were analyzed using dependent t-test.

RESULTS: Findings indicated that there was a significant difference in the level of anxiety $(p=0.041)$ and level of pain $(p=0.001)$ in the intervention group.

CONCLUSIONS: There is an effect of giving self-hypnosis model (SHM) to decrease anxiety and pain in postgeneral anesthesia patients.
\end{abstract}

\section{Introduction}

Surgical and anesthetic actions are potential or actual threats to one's integrity, generating stress reactions both physiologically and psychologically. Physiological stress reactions are directly related to surgery and anesthesia. Each patient responds differently both physiologically and psychologically to surgery. Anxiety can also be affected by the type of surgery, the severity of the surgery, the severity of the disease, and the preparation for surgery/ anesthesia, both physically and psychologically. General psychological responses are related to fear of anesthesia, pain, uncertain diagnosis, malignancy, incompetence, failure, surgical room environment, and horrifying stories from others [1].

The impact of pre-anesthesia anxiety is disruptive to the process of pre-anesthesia and durante anesthesia. Excessive physiological responses tend to complicate and affect anesthetic actions. These responses can affect body systems such as cardiovascular disease - causing palpitations, increased heartbeat, increased blood pressure, faint, decreased blood pressure, and decreased pulse. In terms of respiratory system, the patient will complain on increased breathing pace, shortness of breath, heavy chest feeling, shallow breathing, throat swelling, sensation of suffocating, and panting [2]. Anxiety can also increase the responses to neuromuscular which can threaten patient safety. The excessive responses can be in the form of increased reflexes, shocked reactions, tremors, tension, unusual movements, and increased response to back pain. As a result of preanesthesia anxiety, it can technically increase the risk of an injured patient or a broken spinal/Spinocan needle in this situation [3].

Besides the patient experiencing anxiety in the hospital, they also often feel pain. The pain reaction actually is felt not exactly in the location of the injured body, but in the strength of the patient's mind. The perceived pain signal that has been sent by the pain receptors will be responded by the brain producing pain in the injured part of the body and it is centered on the brain which then triggers the sensation of pain in the patient's body.

In the perspective of professional nurse, one of the basic nursing interventions is providing nonpharmacological therapy which is a complement to conventional therapies and it is proven to be beneficial. Non-pharmacological therapies to reduce pain are including warm compresses, cold compresses, hydrotherapy, acupressure, acupuncture, electronic nerve stimulation per transcutaneous (TENS), hypnotherapy, yoga, biofeedback, relaxation with the 
help of music, imagination, visualization, and aroma therapy [4].

Hypnosis (either using the guidance of others or self-hypnosis model method) has been used for centuries as a way to control pain and anxiety. This way of controlling pain is often related to religious practices that have been conducted throughout the world and exists in various cultures until now. There is a ritual to endure pain that is supposed to be very painful, but since the mind is so focused on the spiritual element, it does not generate any pain. As with meditation practice, someone who is able to reach the deepest level of hypnosis, the brain is able to ignore or "turn off" the pain receptors that they should feel.

Based on the description above, to help reducing the level of pain and anxiety of patients, nonpharmacological therapy of hypnosis can be used. Cognitive intervention through hypnosis works primarily on the cerebral cortex, the part of the brain to think, the limbic system, and the emotional part of the brain that communicates with other parts of the body (such as the hypothalamus, sympathetic nervous system, and parasympathetic) [5].

Self-hypnosis model (SHM) is the application of hypnosis that uses the power of communication (verbal and non-verbal) and imagination techniques to interact with the human subconscious creating a state of relaxation, overcoming physical pain and anxiety, and accelerating the recovery process. Based on the background, this research objective is "There are effects of self-hypnosis model in reducing the anxiety and pain on post-anesthesia patients."

\section{Method}

This was a quasi-experimental study with pretest-posttest design with the control group. Data were conducted at Sleman District Hospital, Yogyakarta, from July to October 2018. The sample of this study was 40 patients who were treated at Sleman District Hospital, Yogyakarta, and met the inclusion and exclusion criteria as follows: Inclusion criteria patients who underwent general anesthesia and were able to communicate actively. The determination of sample size used two-sample test proportion formula. The sample size for each group was consisted of 20 respondents. Sampling technique was simple random sampling. The intervention group was given SHM, the day before surgery. SHM interventions are provided by trained nurses. The patient performs SHM under the guidance of a trained nurse for 3 days after surgery. The control group was given brochures on SHM without being taught how to do it and without nurse assistance. The measuring instrument used in this study was State Trait Anxiety Inventory. Pain was measured by the Numerical Pain Rating Scale, the scale used was $0-10$. The researchers conducted a univariate analysis with a descriptive variable analysis. Descriptive analysis was carried out to describe each variable examined separately by creating a frequency table for each variable. The test used the dependent sample t-test. This study has been approved by the commission of conduct research No.LB.01.01/KE-02/XXIX/679/2018 on August 14, 2018.

\section{Results}

\section{Respondents' characteristics}

The characteristics of respondents are humogen on age and education, un-humogen on sex (Table 1).

Table 1: Characteristics frequency distribution of respondent in the intervention and control groups

\begin{tabular}{|c|c|c|c|c|c|}
\hline \multirow[t]{3}{*}{ Characteristics } & \multicolumn{4}{|c|}{ Group } & \multirow[t]{3}{*}{$\mathrm{p}$ value } \\
\hline & \multicolumn{2}{|c|}{ Intervention } & \multicolumn{2}{|c|}{ Control } & \\
\hline & $\mathrm{n}$ & (\%) & $\mathrm{n}$ & $\%$ & \\
\hline \multicolumn{6}{|l|}{ Sex } \\
\hline Female & 13 & 65 & 11 & 55 & \multirow[t]{2}{*}{0.001} \\
\hline Male & 7 & 35 & 9 & 45 & \\
\hline \multicolumn{6}{|l|}{ Age } \\
\hline $41-40$ & 3 & 15 & 2 & 10 & \multirow[t]{4}{*}{0.059} \\
\hline $41-50$ & 5 & 25 & 3 & 15 & \\
\hline $51-60$ & 7 & 35 & 7 & 35 & \\
\hline$>60$ & 5 & 25 & 8 & 40 & \\
\hline \multicolumn{6}{|l|}{ Education } \\
\hline PS & 1 & 5 & 3 & 15 & \multirow[t]{4}{*}{0.28} \\
\hline $\mathrm{JHS}^{*}$ & 4 & 20 & 3 & 15 & \\
\hline $\mathrm{SHS}^{*}$ & 13 & 65 & 9 & 45 & \\
\hline $\mathrm{HE}^{*}$ & 2 & 10 & 5 & 25 & \\
\hline
\end{tabular}

\section{Anxiety level}

Hypothesis test result shows that there are significant differences in anxiety levels before and after the application of self-hypnosis model (SHM) with $p=0.041$, which means $p<0.05$ (Table 2).

Table 2: Anxiety level frequency distribution of pre- and post-test on the intervention and control groups

\begin{tabular}{|c|c|c|c|c|c|c|c|c|}
\hline \multirow[t]{3}{*}{ Anxiety level } & \multicolumn{4}{|c|}{ Treatment } & \multicolumn{4}{|c|}{ Control } \\
\hline & \multicolumn{2}{|c|}{ Pre } & \multicolumn{2}{|c|}{ Post } & \multicolumn{2}{|c|}{ Pre } & \multicolumn{2}{|c|}{ Post } \\
\hline & $n$ & $\%$ & $n$ & $\%$ & $n$ & $\%$ & $\mathrm{n}$ & $\%$ \\
\hline Severe & 11 & 55 & 4 & 20 & 5 & 25 & 5 & 25 \\
\hline Moderate & 5 & 25 & 7 & 35 & 8 & 40 & 9 & 45 \\
\hline Mild & 4 & 20 & 9 & 45 & 7 & 35 & 6 & 30 \\
\hline$z=-3.464$ & & $p=0$ & & & & & & \\
\hline
\end{tabular}

\section{Pain level}

Hypothesis test result shows that there are significant differences in the level of pain before and after the application of self-hypnosis models with $p=0.001$, which means $p<0.05$ (Table 3). 
Table 3: Anxiety level frequency distribution of pre- and post-test on the intervention group and control group

\begin{tabular}{|c|c|c|c|c|c|c|c|c|}
\hline \multirow[t]{3}{*}{ Pain level } & \multicolumn{4}{|c|}{ Treatment } & \multicolumn{4}{|c|}{ Control } \\
\hline & \multicolumn{2}{|c|}{ Pre } & \multicolumn{2}{|c|}{ Post } & \multicolumn{2}{|c|}{ Pre } & \multicolumn{2}{|c|}{ Post } \\
\hline & $\mathrm{n}$ & $\%$ & $\mathrm{n}$ & $\%$ & $\mathrm{n}$ & $\%$ & $\mathrm{n}$ & $\%$ \\
\hline Severe & 13 & 65 & 4 & 20 & 5 & 25 & 7 & 35 \\
\hline Moderate & 5 & 25 & 7 & 35 & 8 & 40 & 8 & 40 \\
\hline $\begin{array}{l}\text { Mild } \\
Z=-3.360\end{array}$ & 2 & $\begin{array}{l}10 \\
p=0.001\end{array}$ & 9 & 45 & 7 & 35 & 5 & 25 \\
\hline
\end{tabular}

\section{Discussion}

The study showed that self-hypnosis model in reducing the anxiety on post-anesthesia patients with $p=0.041$. Anxiety refers to feelings generated by nonspecific threats to one's self-concept regarding health, assets, values, environment, role functions, and feelings of security [6].

The onset and clinical process of anxiety disorders varies widely. Onset can occur acutely or gradually. Onset can occur without a trigger event or due to acute events that cause stress or chronic stressors such as health problems, work, nutrition, medication, or family. Anxiety disorders are characterized by high levels of anxiety that is seen in unusual behavior such as fear of events which are not based on the reality [7].

The cause of fear is seen as a threat to patients' safety because it has not been resolved. The cause of fear is often unknown because it is hidden in the subconscious mind overtime. The therapist must go deeper to find the root of the problem. By understanding the root of the problem that makes them afraid, the patient will be able to eliminate his anxiety [8].

Hypnotherapy is the art of communication to influence someone to change the level of awareness by controlling one's emotions with a series of activities. Hypnotherapy can be used to eliminate some bad habits of someone or to make him or her in the state of peace [9].

Under cerebral cortical hypnotherapy, someone experiences strong obstruction resulting to the decrease of the identification power, analysis, and decision-making on new stimulus. Other than this, the past experience cannot be used, so suggestive words become a dominant force that cannot be denied. Through active direction of the psychological condition and behavior, the physiology of the patient can be controlled [10].

The study showed that self-hypnosis model in reducing the pain on post-anesthesia patients with $p=0.001$ which means $p<0.05$. Hypnotherapy guides patients to relaxation. This relaxation response occurs through a significant reduction of oxygen demand by the body, then the relaxed muscles generate a feeling of calm and comfort. Blood flow will go smoothly, soothing neurotransmitters will be released, and the nervous system will work properly. After the relaxation condition is reached, the gates of the subconscious mind will naturally open. It results to the easier acceptance of healing suggestion given. In this condition, the pain gate called substantial gelatinous (kornu dorsalis medulla spinalis) will be closed and impulses transmitted to the brain are reduced, so the pain perception in the elderly is lost or reduced [11]

Hypnotherapy done by the elderly will affect the work of the cerebral cortex in cognitive and emotional aspects, resulting in positive perception and relaxation. It will indirectly help in maintaining the balance of body homeostasis through the HPA axis to produce corticotrophin-releasing factor (CRF). Furthermore, CRF stimulates the pituitary gland to reduce $A C T H$ production resulting to the increase of endorphin production which then decreases the production of cortisol and other stress hormones which at the end is able to decrease the pain.

Physiology of pain in post-surgical patients is initiated as a response received by the peripheral nerves. Chemicals such as $\mathrm{P}$ substance, bradykinin, and prostaglandins are released. Then, it stimulates peripheral nerves, helping to deliver excitatory pain from the injured area to the brain. Pain signals from the injured area go as electrochemical impulses along the nerve to the dorsal spinal cord (the area of the spinal that receives signals from the whole body). The message is then delivered to the thalamus, the sensory center in the brain, and sensations such as heat, cold, pain, and touch are first perceived. Then, the message is delivered to the cortex where the intensity and location of pain are perceived. Pain relief begins as a sign from the brain and then goes into the spinal cord. In the dorsal part, chemicals such as endorphins are released to reduce pain in the injured area [12]. In the treatment group, pain is reduced after the application of hypnotherapy. P substance pain receptors are obstructed by endorphin and encephalin which are natural pain killer whose action is stronger than morphine. By that, the patients feel more comfortable and less painful. According to the theory, it is explained that hypnotherapy stimulates the brain to release neurotransmitters, encephalin, and endorphin functioning to improve the mood, so it can change individual's acceptance of pain or other physical symptoms. It will happen if one reaches the maximum trance. By affirming a suggestion that can generate mesencephalon (midbrain), in a hypnotized state, the optimal dopamine will be released and the nigra substance found in the midbrain is activated [13]. Encephalin obstructs the release of $P$ substance in the dorsal cornu spinal cord. Encephalin has a weak analgesic effect than other endorphins but works longer than morphine [14].

The process of hypnotherapy can reduce pain due to the modulation or strengthening of 
impulses from weak impulses/weak stimulation, so it can immediately reach the brain. In hypnotherapy, it is done by giving suggestions using an affirmation in the form of imperative sentences. It is intended that the hypnotic object is able to immediately enter the subconscious mind and it is given a suggestion, so the object will work based on the sentences in the affirmation [13].

In theory, it is said that the encephalin and endorphin explain how people feel differently on the level of pain from the same stimulus. Endorphin levels are different for each individual. Individuals with high endorphins feel less pain and individuals with less endorphin feel greater pain. Patients can express their pain in various ways, from facial expressions, verbal responses, and body movements. The expression shown by the patient is used by nurses to recognize the behavior patterns which indicate pain. Nurses must conduct a careful assessment if the patient expresses a little pain, because not expressing pain does not mean they do not experience pain [11].

\section{Conclusions}

There is an effect of giving self-hypnosis model (SHM) to decrease anxiety and pain in post-general anesthesia patients.

\section{Acknowledgments}

This research was supported by Poltekkes Kemenkes Yogyakarta. We thank our colleague's nurses from Sleman District Hospital, Yogyakarta, who provided insight that greatly assisted the research.

\section{References}

1. Bobak I, Lowdermilk D, Jensen MI. Maternity Nursing. San Francisco: Mosby; 2009.

2. Stuart GW, Sundeen SJ. In: Yani SA, editor. Buku Saku Keperawatan Jiwa. $6^{\text {th }}$ ed. Jakarta: EGC; 2005

3. Sheila L. Buku Ajar Keperawatan Jiwa. Jakarta: EGC; 2008.

4. Ancheta R, Simkin P. Buku Saku Persalinan. Jakarta: EGC; 2005.

5. Carpenito LJ. In: Asih Y, editor. Buku Saku Diagnosa Keperawatan. 10 $0^{\text {th }}$ ed. Jakarta: EGC; 2007.

6. Valente JS. The Role of Self-Directed Learning in Older Adults Health Care. Athens, GA: University of Georgia; 2005.

7. Gunawan AW. Hypnotherapy: The Art of Subconscious Restructuring. Jakarta: Gramedia Pustaka Utama; 2007.

8. Susilo A, Kemala E. In: Handayani D, editor. Hipnotis Metode Terapi Untuk Kesuksesan Karier dan Menghilangkan Kebiasaan Buruk Dengan Hipnoterapi. Jakarta: Gudang IImu; 2010.

9. Desen W, Japaries W. Buku Ajar Onkologi Klinis. $2^{\text {nd }}$ ed. Jakarta: FKUI; 2011.

10. Potter PA, Perry AG. Buku Ajar Fundamental Keperawatan: Konsep, Proses, dan Praktik. Vol. 4. Jakarta: EGC; 2005.

11. VandeVusse L, Irland J, Healthcare WF, Berner MA, Fuller S, Adams D. Hypnosis for childbirth: A retrospective comparative analysis of outcomes in one obstetrician's practice. Am J Clin Hypn. 2007;50(2):109-19. https://doi.org/10.1080/00029157.20 07.10401608

PMid: 18030923

12. Budi PP, Rizali E. Cara Cepat Menguasai Hypno Healing Hipnosis Untuk Menyembuhkan. Yogyakarta: Grafina Mediacipta CV; 2010.

13. Price SA, Wilson LM. In: Pendit BU, Hartanto $H$, Wulansari $P$, Maharani DA, editors. Patifisologi: Konsep Klinis Proses-Proses, Penyakit. $6^{\text {th }}$ ed., Vol. 2. Jakarta: Penerbit Buku Kedokteran EGC; 2005.

14. Waugh A, Grant A. Ross and Wilson: Anatomy and Physiology in Health and IIIness. $12^{\text {th }}$ ed. Netherlands: Churcill Livingstone, Elsevier; 2014 